\title{
Post-traumatic diaphragmatic ruptures - 12 years experience
}

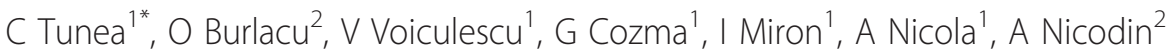 \\ From 23rd World Congress of the World Society of Cardio-Thoracic Surgeons \\ Split, Croatia. 12-15 September 2013
}

\section{Background}

Undetected post-traumatic trans-diaphragmatic hernias due to once minor diaphragmatic lacerations can lead over time to serious complications. Early recognition and treatment are mandatory to minimize complication.

\section{Methods}

We reviewed retrospectively the charts of 18 patients admitted between 2001and 2012, presenting with diaphragmatic lacerations post trauma. We noted the traumatic mechanism, involvement of other organs, diagnostic methods, surgical approach, and postoperative stay. All patients were submitted to open surgery. The surgical repair of the diaphragm was performed using double layer in separate stitches. We used average with standard deviation and correlation Pearson index.

\section{Results}

We had a 0,2 ratio female/male, mean age $41.88 \pm 17,08$ years. The mechanism of injury was 5 stabbing wounds, 5 rib fractures, 4 crash syndrome, and 4 decelerations. 15 cases were operated on as an immediate emergency, 3 cases were delayed. The surgery was: thoracic in 15 and thoraco-abdominal in 3 cases. We noted 3 complications. Pearson index for age-postoperative days was 0.241.

\section{Conclusions}

Due to the serious short and long term complications and lesion associations, post-traumatic diaphragmatic lacerations must be approached early and by a multidisciplinary surgical team. In a poli-traumatized patient with severe bleeding often minimally invasive approach is in our opinion not sufficient.

\footnotetext{
* Correspondence: calin.tunea@gmail.com

'Department of Thoracic Surgery, Emergency Municipal Hospital Timisoara, Romania
}

Full list of author information is available at the end of the article

\section{Authors' details}

${ }^{1}$ Department of Thoracic Surgery, Emergency Municipal Hospital Timisoara, Romania. ${ }^{2}$ University of Medicine, Timisoara, Romania.

Published: 11 September 2013

\section{doi:10.1186/1749-8090-8-S1-076}

Cite this article as: Tunea et al:: Post-traumatic diaphragmatic ruptures - 12 years experience. Journal of Cardiothoracic Surgery 2013 8(Suppl 1): 076.
Submit your next manuscript to BioMed Central and take full advantage of:

- Convenient online submission

- Thorough peer review

- No space constraints or color figure charges

- Immediate publication on acceptance

- Inclusion in PubMed, CAS, Scopus and Google Scholar

- Research which is freely available for redistribution

Submit your manuscript at www.biomedcentral.com/submit
() Biomed Central

\section{Biomed Central}

